\title{
MLL/CASC5 Fusion Protein
}

National Cancer Institute

\section{Source}

National Cancer Institute. MLL/CASC5 Fusion Protein. NCI Thesaurus. Code C99350.

A fusion protein encoded by the MLL/CASC5 fusion gene. This protein is comprised of the $\mathrm{N}$-terminal half of the histone-lysine $\mathrm{N}$-methyltransferase MLL protein, including the AT hook DNA binding domain and the DNA methyltransferase domain, fused to the Cterminal coiled-coil domain of protein CASC5. 